\title{
小ロ径配管用高性能スパイラルフロー空気輸送装置
}

\section{—スパイラルフローノズルの特性 —}

\section{High Performance Spiral Flow Pneumatic Conveying System for Small Diameter Pipelines Characteristics of Spiral Flow Nozzle -}

\author{
木 村 治 基 ${ }^{* 1}$, 瀧 野 孔 延 ${ }^{* 1}$, 上田 寛 ${ }^{* 2}$, 趙 耀 華*3 \\ Harumoto KIMURA, Yorinobu TAKINO, Hiroshi UEDA, Yao-Hua ZHAO \\ 富田 侑 嗣 ${ }^{* 4}$, 渡邊敬 三 ${ }^{* 5}$, 堀井 清 之*6 \\ Yuji TOMITA, Keizo WATANABE, Kiyosi HORII
}

\begin{abstract}
High performance pneumatic conveying system for small diameter pipeline using a spiral flow has been developed. The new system has overcome the drawbacks of spiral flow nozzles that have no suction capacity when pipeline is prolonged, because the pressure drop increases more than the pressure recovery of the nozzle. With this system, particles are transported through $19 \mathrm{~mm}$-diameter pipelines over a distance of 50meters. Furthermore, when this system is installed as boosters in long pipelines, the limit of particle transportation distances will be eliminated. The essential feature of the system is the control of particle feeding capacity by bleeding off some of air from the outlet of nozzle, resulting in precise adjustment of mixing ratio.
\end{abstract}

Key Words : Pneumatic Conveying, Small Diameter Pipeline, Pressure Recovery, Suction Ability, Spiral Flow

\section{1. 緒 言}

近年，多品種少量生産を行なうプラントにおいて， 従来の空気輸送装置では稼働率の低下や設置スペース あるいは設備コストの増加といった問題点が見受けら れ, 特に品種替え時の残材抜取りや次ロットの段取り に多くの労力を費やしている。

これらの欠点は, 従来の空気輸送装置がロータリー バルブなどの機械的な供給手段, 或いは吸引輸送・高

1988年1月 22 日受付

(粎松井製作所技術開発センター

* 1 ( ₹573-0102 大阪府枚方市長尾家具町 1-10-4)

TEL 0720-51-6136

Matsui MFG. Co., Ltd., R \& D Center

(1-10-4, Nagao-Kagumachi, Hirakata-shi, Osaka 573-0102)

$* 2$ 大䲮薬品工業(㧣品質管理部

（元771-0194 徳島市川内町平石夷野224-2） TEL 0886-65-6054

Taiho Pharmaceutical Co., Ltd. Quality Control

Department

(224-2 Ebisuno, Hiraishi, Kawauchi-cho, Tokushima 771-0194)

*3 東京大学生産技術研究所

（テ106-0032 東京都港区六本木7-22-1）TEL 03-3402-6231 University of Tokyo (7-22-1, Ropongi, Minatoku, Tokyo 106-0032)
濃度輸送に必要となる気密ホッパー, さらには固定式 の輸送配管などを用いていることが原因とされる。空 気輸送装置を多品種少量生産に適応させるためには, 装置の簡素化と小型化だけでなく，輸送ラインの簡便 な切り替えも必要とされている。

しかしながら装置の小型化や簡素化は, 輸送負荷の 増加に伴うさまざまな問題を誘発する。たとえば，輸 送配管の小口径化により長距離輸送における圧力損失 が装置の昇圧能力を上回り輸送不可となる，等がその 一例である。

本研究の目的は, これらの流体力学的問題をスパイ ラルフローノズル"1) の使用とブリード機構, すなわち

* 4九州工業大学工学部機械知能工学科

（テ804-0015 北九州市戸畑区仙水町 1-1） TEL 093-884-3157 Kyushu Institute \& Technology (1-1, Sensuimachi, Tobataku, Kitakyushu 804-0015)

* 5東京都立大学工学研究科機械工学専攻

（テ192-0364 東京都八王子市南大沢 1-1）TEL 0462-77-2706

Tokyo Metropolitan University (1-1, Minami-osawa, Hachioji-shi, Tokyo 192-0364)

*6白百合女子大学文学部

（テ182-0001 東京都調布市緑ヶ丘 1-25）TEL 03-3326-7604 Shirayuri Women's College (1-25, Midorigaoka, Chofushi, Tokyo 182-0001) 


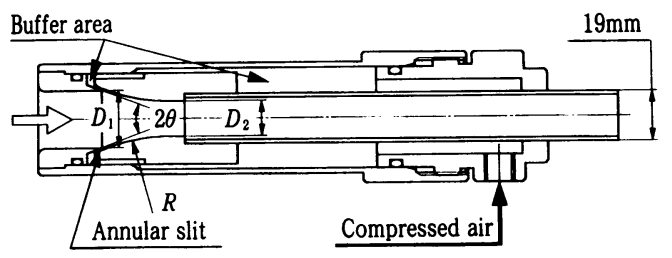

Fig. 1 Spiral flow nozzle

輸送配管に供給される気流の一部を外気に流出させる ことにより解決することであり, 効果的な粉粒体輸送 の機構を実験と理論解析により解明するべく研究を行 なってきた。本報では空気輸送におけるスパイラルフ ローノズルの特性について述べる。

\section{2. 新しい輸送方式に対するコンセプト}

\section{1 スパイラルフローノズル}

空気輸送機への応用を考慮したスパイラルフローノ ズルの構造を Fig. 1 に示す。バッファー部に導入され た圧空が傾斜した環状スリットよりノズル内に噴出

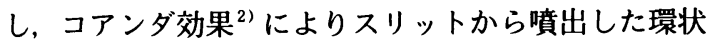
ジェットは, 湾曲したノズル内壁面にそって軸方向に 流れを変える。このとき, 軸方向の乱れ成分は周方向 に逃げ, 安定したスパイラル構造と軸方向に急峻な速 度分布を持った流れになる3.4)。一般的な旋回流れは 接線方向の流れを与えて発生させているのに対し， ス パイラルフローノズルでは接線方向の流れを与えるこ となくスパイラル構造の流れを発生させている。この スパイラル流の自生的とも思える発生現象は, 乱流の 持つ特有の非対称性・乱れと深い関わりがあり,これ らによって起こるノズル上流部と下流部の軸速度の半 径方向の非対称性に起因すると思われる ${ }^{5)}$ 。

また，ノズル入口付近に存在する粉粒体は, 周囲の 空気と共にノズル内に吸引されノズル出口から排出さ れるが，ノズル出口に輸送配管を接続しておけば空気 輸送が可能となり，機械的な供給機構や気密性ホッ パーの不要な簡易な空気輸送装置を構成することがで きる。さらに，ノズル出口に対して入口側の口径が大 きくなる形状をしており，ノズル内部では噴流による 流動化作用もあるため, 粉粒体のブリッジ現象を防止 し，小口径配管への供給に適した構造となっている。

本実験に用いたノズルによって発生するスパイラル フローの程度は, 自由渦領域の占める割合が高く, ス ワール数 $S$ は 0.3 , その軸速度分布は直線流のそれよ り急峻であり, 軸変動速度は $60 \%$ 減少している。 尚, スワール数 $S$ は次式より求まる ${ }^{6)}$ 。

$$
S=\frac{\frac{1}{2} G}{1-\frac{1}{4} G^{2}}, \quad G=\frac{v_{\theta \max }}{v_{\mathrm{z} \max }}
$$

ただし, 旋回の回転方向は乱流の乱れ・非対称性に起 因するためか特定できないが，一度方向が定まると持 続する。一般的には流れに対し右回りが多い7)。

また，その輸送に対する効果として, 急峻な軸速度 分布による圧力損失の低减, 低い軸変動速度が, 輸送 効率向上に寄与すると思われる。よって, スパイラル フローは吸引口におけるより, その後の管内輸送にお いて重要であると考える。

\section{2 ブリード機構}

ノズルの輸送動力源としての性能は, 供給流量や回 収圧力すなわちノズル出口においての入口部からの増 加圧力, さらに管内圧力損失等の物理的因子に支配さ れる。供給流量の増大は粒子の搬送能力の増加につな がるが, 輸送管内の圧力損失は供給流量の増加に伴い 管内風速のおよそ二乗に比例して増加する。管内風速 が増加しノズルの回収圧力に近つくく搬送能力の低下 が生じ，压力損失がノズルの回収圧力を上回れば粒子 の自吸は不可能である。

この問題を解決するため, 輸送配管に供給される気 流の一部を外気に流出させる機構（ブリード機構）を 考案した。この機構により管内流速の不要な増加を抑 え, ノズルの吸気能力を改善することで, 圧空の過剩 供給時においても粉粒体の吸引能力は維持できると考 えられる。

\section{3. 実験方法}

\section{1 装置条件}

実験には 4 種類のノズルを用い，その寸法を Table 1 に示す。環状スリットの噴出角度 $\theta$ は $20^{\circ}$ とし, ノズル $\mathrm{A} ・ \mathrm{~B}$ およびC は環状スリットから曲面管に至 る形状を幾何学的相似形とした。ノズルに供給した圧 縮空気の圧力は，ノズル内のバッファー部において ゲージ圧 0.3MPa となるようにした。

\section{2 スパイラルフローノズルの流体力学特性の調}

\section{査}

まず，各接続配管長において供給風量が管内平均風 速およびノズルの吸気風量に与える影響を調查した。 使用したノズル形状はBタイプで，ノズル出口には内 径 $19 \mathrm{~mm}$ の PVC ホースを接続した。さらに, ノズ ルの吸気風量がゼロとなる負荷状態における回収圧力 をノズルの最大回収圧力と定義し，ノズル形状が最大 
Table 1 Properties of nozzles

\begin{tabular}{r|cccc}
\hline Nozzle type & A & B & C & D \\
\hline Diameter of annular slit $; D_{1}, \quad(\mathrm{~mm})$ & 18 & 22 & 28 & 28 \\
Diameter of throat $; D_{2}, \quad(\mathrm{~mm})$ & 10.7 & 13.4 & 17 & 10.7 \\
Radius of round wall $;, \quad(\mathrm{mm})$ & 62 & 74 & 90 & 137 \\
\hline
\end{tabular}

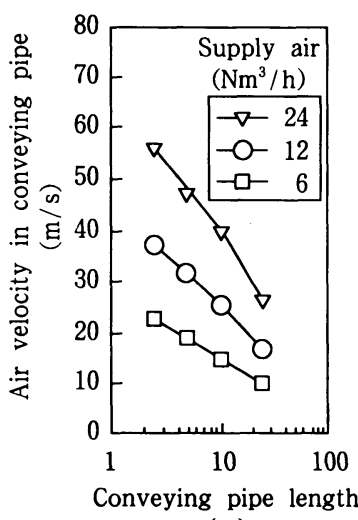

(m)

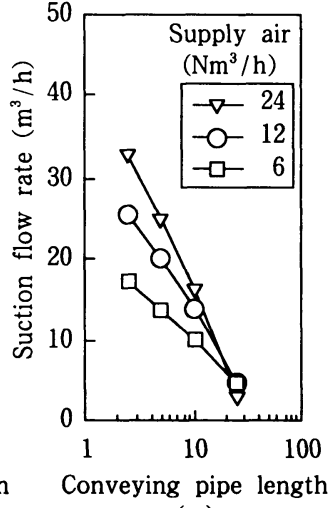

(m)
Fig. 2 Characteristics of spiral flow nozzle (type B nozzle)

回収圧力に与える影響を調査した。

\section{3 ブリード機構の効果確認}

次に, ノズル排気エアーのブリード量がノズル性能 に与える影響を比較するため, ノズル出口のホース接 続部分に直径 $3 \mathrm{~mm}$ の孔を 2 個所または 5 個所開け,

Bタイプのノズルを用いて孔個数の違いによる差異を 調査した。接続ホース・供給圧力などの条件は先に計 測した条件に合わせた。なお，これまでの実験では粒 子の供給は行っていない。

\section{4 材料輸送実験}

最後に, PMMA ペレットを使用しての輸送実験を 行なったが，ノズルへの材料供給はタンク内の材料に ノズルを $45^{\circ}$ 傾斜させて差し込むのみとし, 他の供 給機は用いていない。使用したノズルはBタイプ, 接 続した配管は内径 $19 \mathrm{~mm}$ の帯電防止剂入り PVC で, 輸送距離は $15 ， 30,50 \mathrm{~m}$ の 3 種類, その他の条件 は無負荷特性計測時と同一とした。これらの条件に基 づき接続配管長および供給風量の違いによる輸送能力 の変化を計測した。

\section{4. 実験結果および考察}

\section{1 スパイラルフローノズルの供給流量に対する 流体力学特性}

Fig. 2 に見られるように, 吸気流量の変化より輸送

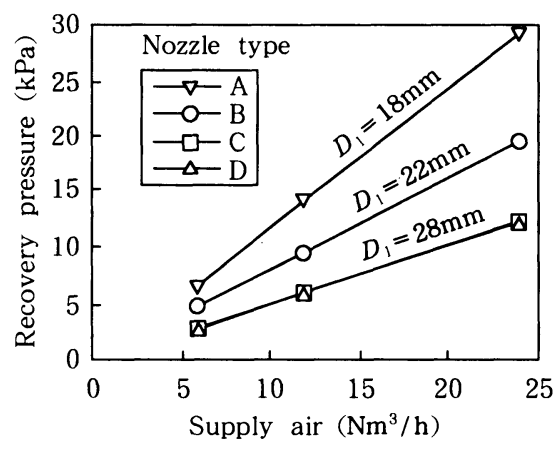

Fig. 3 Maximum recovery pressure

限界は約 $30 \mathrm{~m}$ と見られる。輸送配管長の増加により 管内流速は減少するが, 通常ならば供給流量を増加 することにより管内流速の減少を抑えることができ る。しかし, ある限界以上の配管長では供給流量を増 加しても背圧のため吸気流量の低下を招く。さらに長 距離になれば吸気量は負となり，吸気能力が無くなる ことは容易に予測できる。つまり粉粒体粒子を吸引 し, 輸送することは不可能である。付け加えれば, 供 給流量の増加は吸気能力の向上には効果的でないと言 える。

小口径長距離配管の粉粒体輸送には，ノズルの高い 回収能力による十分な吸気流量が必要であるが，最大 回収圧力はある供給流量において各ノズルの環状スリ ットの口径 $D_{1}$ にほぼ反比例することが Fig. 3よりわか る。

スパイラルフローノズルは粉粒体の小口径長距離輸 送に対し高い可能性を有すると思われるが，輸送距離 の増加に伴う压損の増加のため吸気能力が減少する, といった従来のインジェクションフィーダー ${ }^{8)}$ と同様 の欠点も持っている。

\section{2 ブリード機構が輸送性能に及ぼす影響}

上記の欠点を解消するため, ノズル排気エアーのブ リード機構を提案したが, このブリード機構により吸 気流量と粉粒体粒子吸引量の増加が見られ，粒子対空 気の混入比が増加した。これは，この機構により余分 な導入空気を外気に放出することで，管内流速の最適 

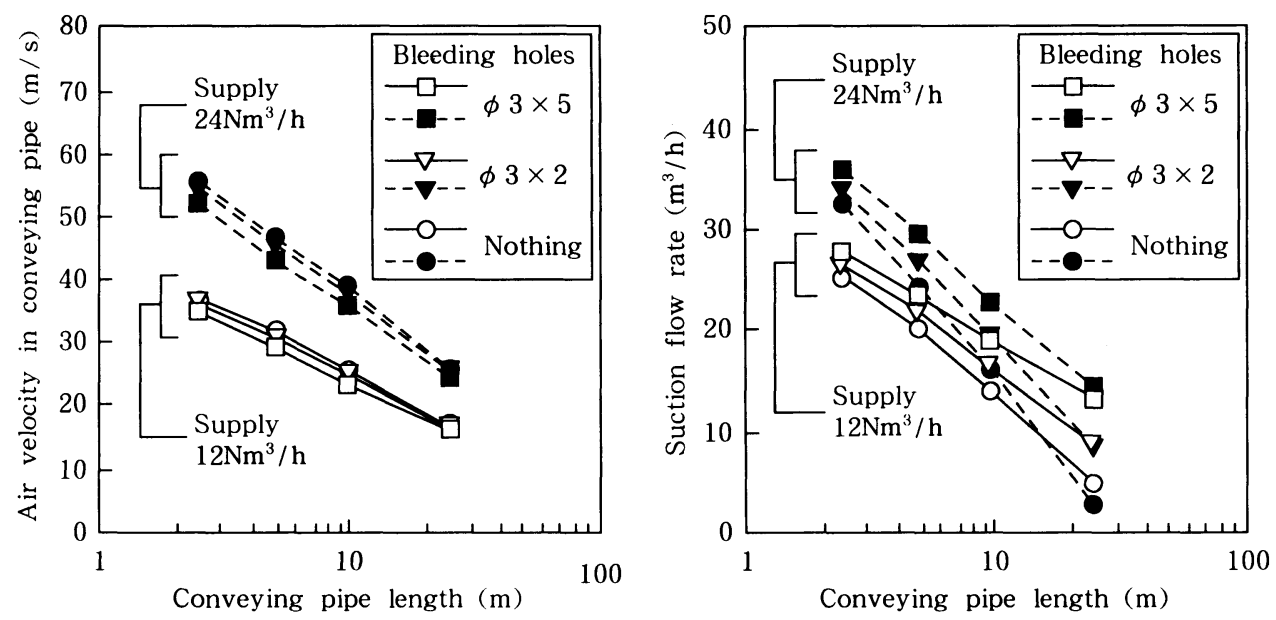

Fig. 4 Effect of bleeding holes on the characteristics (type B nozzle)

化・圧損の低減・回収圧力の向上といった輸送に適し た状態を作り上げたためと考えられる。

Fig. 4 に輸送距離に対するブリード機構の効果を示 す。ブリード孔を増すほど吸気流量は増加し, 輸送配 管距離が長いほど，また供給流量が多いほど顕著であ る。配管長 $25 \mathrm{~m}$ においては, ブリード孔を 5 個所設 けたものはブリード孔の無いものに比へ吸気風量が約 3倍になっている。しかし管内流速についてはブリー ド機構による大きな変化は見られない。

輸送能力については, 翰送距離 30〜 50m におい て, ブリード機構のない場合に比べブリード孔を 5 個 所設けたものは輸送能力が約 4 倍に増加していること が Fig. 5 よりわかる。また輸送能力はブリード孔の個 数すなわち断面積を変えることにより調節が可能であ ると言える。

さらに，ブリード機構を付加したスパイラルフロー ノズルを輸送管途中に設置すれば，さらに長距離の輸 送も可能であることも付け加えておく。

\section{5. 理論解析}

理論解析における装置内空気流の略図を Fig. 6 に示 す。流れは压空供給部付近とそれ以外の二力所に分け て取り扱い，実験条件より噴流の速度はおおよそ音速 に達するため, 圧空供給部付近の流れは圧縮性流体と し，他は非圧縮性と見なした。

\section{1 最大回収圧力}

回収圧力は運動量の法則に基づくものとし，ノズル の環状スリットから喉部までを検査面とすると，運動 量の式は次式で表される。

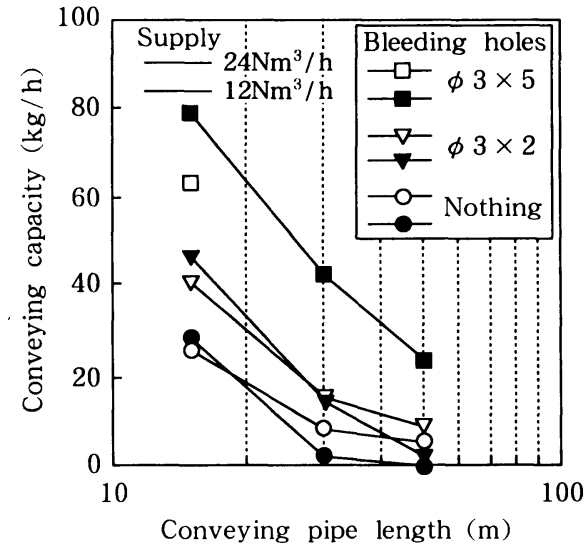

Fig. 5 Effect of bleeding holes on the conveying capacity of particles (type B nozzle)

$\varepsilon \rho_{1} Q_{1} U_{1}+\rho Q_{3} U_{3}-\rho Q_{2} U_{2}=p_{2} A_{2}-p_{3} A_{3}+F_{z}$

ここで $\varepsilon$ はコンダ効果係数であり $\cos \theta$ から 1 の值 をとるが, 本研究においては,

$$
\varepsilon=(\cos \theta+1) / 2
$$

とした。添字 $1 ， 2$ 及び 3 はそれぞれ，環状スリット 部，ノズル喉部，ノズル入口部を表す。また， $F_{z}$ はおよそ次式により与えられる。

$$
F_{2} \cong p_{3}\left(A_{3}-A_{2}\right)
$$

つまり，ノズル曲面管壁での静圧力がノズル入口部 


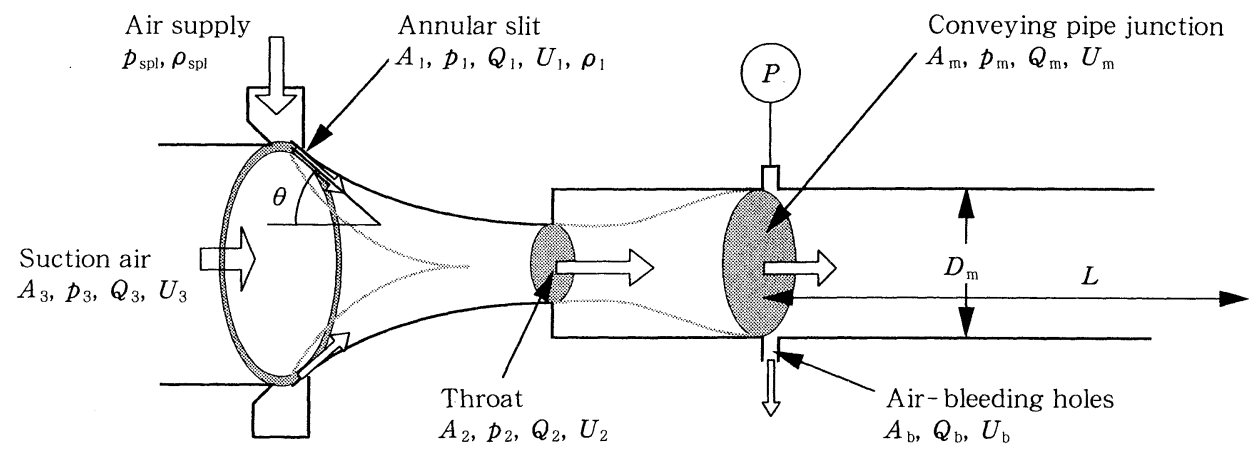

Fig. 6 Analysis flow field

での圧力 $p_{3}$ で近似された。Eqs. (2)，(4) より, 喉部 の圧力 $p_{2}$ は以下の式で得られる。

$$
\begin{aligned}
& p_{2}=\frac{1}{A_{2}}\left(\varepsilon \rho_{1} Q_{1} U_{1}+\rho Q_{3} U_{3}-\rho Q_{2} U_{2}\right)+p_{3} \\
& \text { ノズル入口部におけるベルヌーイの式は } \\
& p_{3}+\frac{1}{2} \rho U_{3}^{2}=p_{0}
\end{aligned}
$$

である。ここで $p_{0}$ は大気圧である。

供給部付近の圧縮性空気流は理想気体の断熱变化と 考えることができ， $\kappa$ を比熱比とすれば供給空気の圧 力 $p_{\text {spl }}$ は臨界圧力より十分に高くまたその流速は無視 することができるため, 環状スリット出口の圧力, 流 速, 密度は先細りノズルと同様に求めることができ $3^{2)}$ 。

$$
\begin{aligned}
& p_{1}=p_{\text {spl }}\left(\frac{2}{\kappa+1}\right)^{\kappa /(\kappa-1)} \\
& U_{1}=\sqrt{\kappa \frac{p_{1}}{\rho_{1}}} \\
& \rho_{1}=\rho_{\text {spl }}\left(\frac{2}{\kappa+1}\right)^{1 /(\kappa-1)}
\end{aligned}
$$

ノズル喉部から回収圧力計測点における運動量の式 は,

$$
\rho U_{\mathrm{m}}^{2} A_{\mathrm{m}}-\rho U_{2}^{2} A_{2}=\left(p_{2}-p_{\mathrm{m}}\right) A_{\mathrm{m}}
$$

であり, $U_{\mathrm{m}} A_{\mathrm{m}}=Q_{\mathrm{m}}, U_{2} A_{2}=Q_{2}$ より, Eq. (10) を 変形し計測点における圧力 $p_{\mathrm{m}}$ は次式で表される。

$$
p_{\mathrm{m}}=p_{2}+\frac{1}{A_{\mathrm{m}}}\left(\rho Q_{2} U_{2}-\rho Q_{\mathrm{m}} U_{\mathrm{m}}\right)
$$

Eqs. (5)，(6)，(11）より計測点における回収圧力 $\left(p_{\mathrm{m}}-p_{0}\right)$ は以下のようにして求まる。

$$
\begin{aligned}
p_{\mathrm{m}}-p_{0} & =\frac{\varepsilon \rho_{1} Q_{1} U_{1}+\rho Q_{3} U_{3}-\rho Q_{2} U_{2}}{A_{2}} \\
& +\frac{\rho Q_{2} U_{2}-\rho Q_{\mathrm{m}} U_{\mathrm{m}}}{A_{\mathrm{m}}}-\frac{1}{2} \rho U_{3}^{2}
\end{aligned}
$$

ブリード機構を持たない場合の本装置における連続 の式は,

$$
\rho_{\mathrm{spl}} Q_{\mathrm{spl}}+\rho Q_{3}=\rho_{1} Q_{1}+\rho Q_{3}=\rho Q_{2}=\rho Q_{\mathrm{m}}
$$

であるが，吸気流量 $\rho Q_{3}$ がゼロになる時の回収圧力を 最大回収圧力としたので，Eq. (13) において $\rho Q_{3}=0$ としてこれをEq. (12) に代入して変形し, 最大回収 圧力 $\left(p_{\text {max }}-p_{0}\right)$ を得る。

$$
p_{\max }-p_{0}=\frac{\rho_{\mathrm{spl}} Q_{\mathrm{spl}} U_{1}}{A_{2}}\left\{\varepsilon-\frac{\rho_{1} A_{1}}{\rho A_{2}}\left(1-\frac{A_{2}}{A_{\mathrm{m}}}+\frac{A_{2}^{2}}{A_{\mathrm{m}}^{2}}\right)\right\}
$$

供給空気压 $p_{\mathrm{spl}}$ が臨界圧力以上であれば $U_{1}$ はおおよ そ音速となり， $A_{1}<<A_{2}, A_{2}<A_{\mathrm{m}}$ であれば，最大回 収圧力は供給流量 $\rho_{\mathrm{spl}} Q_{\mathrm{spl}}$ に比例しノズル喉部断面積 $A_{2}$ に反比例することを示している。しかしながら Fig. 3およびTable 1よりわかるように，実験結果に おいては喉径の等しいノズル A・Dよりも環状スリッ ト口径の等しいノズルC・Dが近似した特性を示して おり, 最大回収圧力は喉部の大きさより環状スリット 径が支配的となっている。そのため運動量の法則にお ける下流側の検査面は実際の喉部の位置ではなく，環 状スリットの径により決定されるものと推定できる。

\section{2 ブリード機構の効果}

ブリード孔を設けた輸送管接続部通過時におけるべ ルヌーイの式は以下の通りである。 


$$
\frac{1}{2} \rho U_{m}^{\prime 2}+p_{m}^{\prime}=\frac{1}{2} \rho U_{m}^{2}+p_{m}
$$

乱流における翰送管内圧力損失 $\Delta p$ は, 次式より求 まる。

$$
\Delta p=p_{\mathrm{m}}^{\prime}-p_{0}=\frac{1}{2} \rho U_{\mathrm{m}}^{\prime 2} \frac{\lambda}{D_{\mathrm{m}}} L
$$

ここで， $D_{\mathrm{m}}$ は輸送管内径であり， $\lambda$ は輸送管内の 乱流時における管摩擦係数である。 $U^{\prime}{ }_{\mathrm{m}}$ は輸送管内 の平均流速であるが通常は輸送される粒子の性状によ り決定される。また $U_{\mathrm{m}}^{\prime}$ は連続の式を満足しなければ ならない。

$$
U_{\mathrm{m}}^{\prime}=\frac{\left(\rho_{1} Q_{1}+\rho Q_{3}-\rho Q_{\mathrm{b}}\right)}{\rho A_{\mathrm{m}}}=\frac{Q_{\mathrm{m}}-Q_{\mathrm{b}}}{A_{\mathrm{m}}}
$$

\section{ノズル排気エアーの流出流量は}

$$
Q_{\mathrm{b}}=\alpha A_{\mathrm{b}} \sqrt{\frac{2}{\rho}\left(p_{\mathrm{m}}-p_{0}\right)}
$$

より求まり， $A_{\mathrm{b}}$ はブリード孔の総面積である。

$\alpha$ はボルダのノズルでは 0.5 , ラウンドノズルでは $0.61 \sim 0.64^{9)}$ であるが, 本研究では $\alpha$ を 0.5 とした。

実験値（Fig. 4）との比較のため，一定の流量を供 給したとき接続された輸送配管長さによる吸気風量の 変化をブリード孔の有無についてそれぞれ求めた。， ズルの回収圧力 $\left(p_{\mathrm{m}}-p_{0}\right)$ と輸送配管内圧力損失 $\Delta p$ は等しくなるため, ブリード孔を有する場合は Eqs. (12)，(16）より次式が成り立つ。

$$
\begin{aligned}
& \frac{\varepsilon \rho_{1} Q_{1} U_{1}+\rho Q_{3} U_{3}-\rho Q_{2} U_{2}}{A_{2}}+\frac{\rho Q_{2} U_{2}-\rho Q^{\prime}{ }_{\mathrm{m}}^{\prime} U_{\mathrm{m}}^{\prime}}{A_{\mathrm{m}}} \\
& -\frac{1}{2} \rho U_{3}^{2}-\frac{1}{2} \rho U^{\prime 2} \frac{\lambda}{D_{\mathrm{m}}} L=0
\end{aligned}
$$

またブリード孔の無い場合は,

$$
Q^{\prime}{ }_{\mathrm{m}}=Q_{\mathrm{m}}, U_{\mathrm{m}}^{\prime}=U_{\mathrm{m}}
$$

となり，ノズルに供給する流量 $24 \mathrm{Nm}^{3} / \mathrm{h}$ の場合にお いてLをパラメータとしてEqs. (13)，(17),（18）を

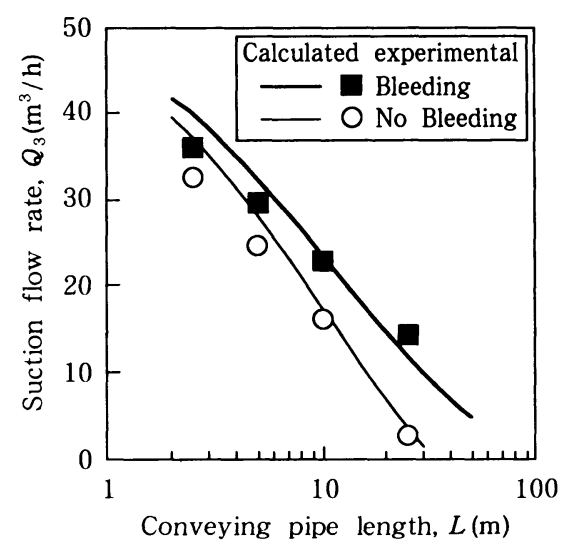

Fig. 7 The comparison between calculated results and measurements, type $B$ nozzle, air supply $=24 \mathrm{Nm}^{3} / \mathrm{h}$, $\phi 3 \times 5$ bleeding holes

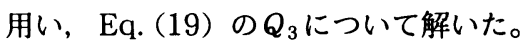

計算結果を Fig. 7 に示すが実験結果とよく一致して いる。輸送配管長 $L$ が短いときの計算値と実験値のず れについては計測器を含む諸損失の影響と見られる。

\section{6. 結 論}

ノズル排気エアーの，ブリード機構を付加したスパ イラルフローノズルによる粉粒体空気輸送について, 以下の結論を得た。

1）スパイラルフローノズルを粉粒体空気輸送のため の動力源と見た場合において，その特性を明らかに することができた。

2）ブリード機構，すなわちスパイラルフローノズル と輸送配管の接合部に，大気に連通する孔を設け不 要な空気流を外気に放出することにより，この機構 が無い場合に発生していた小口径長距離輸送時にお ける吸気能力の消失という問題を解決することがで きた。

3）ブリード機構を付加することにより, 同一輸送距 離であれば約 4 倍の輸送能力を得ることができ，こ の輸送能力はまたブリード孔の断面積を変えること で調整可能である。

\section{Nomenclature}

$A \quad$ : cross section aria

$\left(\mathrm{m}^{2}\right)$

$D \quad$ : inside diameter of nozzle and conveying pipe (m)

$G \quad$ : ratio between maximum azimuthal velocity and axial velocity
$L \quad$ : conveying pipe length

(m)

$p, p^{\prime}$ : absolute pressure (no bleeding, bleeding)

$p_{\max }:$ maximum recovery pressure

$Q, Q^{\prime}$ : quanity of air flow (no bleeding, bleeding) $\left(\mathrm{m}^{3} / \mathrm{s}\right)$ 
$S \quad$ : swirl number

$U, U^{\prime}$ : mean air velocity (no bleeding, bleeding) $(\mathrm{m} / \mathrm{s})$

$v_{0 \max }:$ maximum azimuthal valocity

$v_{z, \max }:$ maximum axial valocity

$\alpha \quad$ : coefficient of discharge

$\Delta p \quad$ : pressure drop in the conveying pipe

$\varepsilon \quad$ : coefficient of Coanda effect

$\kappa \quad:$ isentropic exponent

$\lambda$ : the resistance coefficient of the turbulent air flow in the conveying pipe

$\theta \quad$ : angle of annular jet

(degree)
(-) $\rho \quad$ : air density

Subscripts

$(\mathrm{m} / \mathrm{s}) \quad 0$ : atmosphere

$(\mathrm{m} / \mathrm{s}) \quad 1$ : annular slit

(-) 2 : nozzle's throat

(Pa) 3 : suction air

(-) b : bleeding holes

(-) $m$ : conveying pipe

and the portion for measuring recovery pressure spl : air supply

\section{References}

1) Horii, K. : "Spiral Flow and Its Industrial Applications”, Turbo Machines, Japan. 22, (No. 4), 56-64 (1994)

2) Nakayama, Y. : "Ryutai no Rikigaku”, Yokendo, 111, 199-201. (1997)

3) Horii, K. : "Pneumatic Conveyance using Spiral Airflow”, J. Soc. Powder Technol., Japan, 24, 542-547 (1987)

4) Horii, K. : "Using Spiral Flow for Optical Cord Passing", Mechanical Engineering-ASME, 112, (No. 8), 68-69 (1990)

5) Cheng, X. M., Y. Matsumae, B. Hashimoto, S. Kage, K. Ohsumi, and K. Horii, : "Flow in Spiral Nozzle for Ropei-nstallation in Petrochemical Piprline Repairs",
Sekiyu Gakkaishi, 35, (No. 5), 382- 389 (1992)

6) Chinger, N. A. and A. Chervinsky, : "Experimental and Theoretical Study of Turbulent Swirling Jets Issuing form A Round Orifice”, Israel J. Technol., 4, 44-54 (1966)

7) Horii, K., Y. Matsumae, X. M. Cheng, M. Takei, E. Yasukawa, and B. Hashimoto, : "Focusing Phenomenon and Stability of Spiral-Flow Jet", Trans. of The Japan Soc. for Aeronautical and Space Sciemces, 33, (No. 102), 141-153 (1991)

8) Jotaki, T. : "Funryutai no Kukiyusou", Nikkan Kogyo, 158. (1985)

9) Wu, W. Y. : "Fluid Dynamics", Peking Univ. Press, 276-289 (1982) 